\title{
Madagascar Beetle, Leichenum canaliculatum variegatum (King) (Insecta: Coleoptera: Tenebrionidae) ${ }^{1}$
}

James C. Dunford and Warren E. Steiner ${ }^{2}$

\section{Introduction}

The Madagascar beetle, Leichenum canaliculatum variegatum (Klug) 1833, presumably a native to Madagascar, was first found in the United States in 1906 at Mobile, Alabama, and was first known to occur in Florida in 1920 (Spilman 1959).

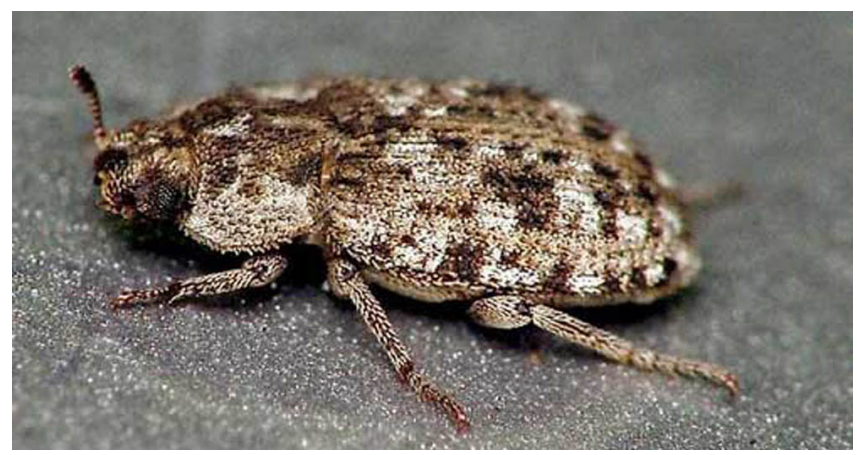

Figure 1. Adult Madagascar beetle, Leichenum canaliculatum variegatum (Klug). Credits: Sean McCann, University of Florida

Leichenum c. variegatum is presently a member of the tenebrionid subfamily Opatrinae. The opatrine lineage is best represented in the Ethiopian and Palearctic faunal regions, and only a small percentage $(\sim 14 \%)$ of the known genera occur in the New World
(Aalbu and Triplehorn 1985). Aalbu and Triplehorn (1985) redefined the opatrine tribes and removed Leichenum from Opatrini and the genus is currently the only representative of the tribe Leichenini in the United States (Aalbu et al. 2002).

Gridelli (1939) revised the genus and gave subspecies status to variegatum, but because of this beetle's cosmopolitan distribution and likely introduced status in many countries, it is not clear why this designation has been provided for $L$. canaliculatum, originally described by Fabricius in 1798 (see Synonymy). It should be noted that many authors do not recognize L. canaliculatum variegatum when listing this species and various combinations of the names listed in the synonymy below appear in the literature.

\section{Synonymy}

[taken from the Australian Faunal Directory 2007]

Leichenum Dejean, 1834 [previously credited to Blanchard 1845, (Bouchard et al. 2005)]

1. This document is EENY-399 (IN723), one of a series of Featured Creatures from the Entomology and Nematology Department, Florida Cooperative Extension Service, Institute of Food and Agricultural Sciences, University of Florida. Published: May 2007. This document is also available on Featured Creatures Website at http://creatures.ifas.ufl.edu. Please visit the EDIS Website at http://edis.ifas.ufl.edu.

2. James C. Dunford, Department of Entomology and Nematology, University of Florida and Warren E. Steiner, Jr., U.S. National Museum of Natural History, Smithsonian Institution.

The Institute of Food and Agricultural Sciences (IFAS) is an Equal Opportunity Institution authorized to provide research, educational information and other services only to individuals and institutions that function with non-discrimination with respect to race, creed, color, religion, age, disability, sex, sexual orientation, marital status, national origin, political opinions or affiliations. U.S. Department of Agriculture, Cooperative Extension Service, University of Florida, IFAS, Florida A. \& M. University Cooperative Extension Program, and Boards of County Commissioners Cooperating. Larry Arrington, Dean 
Leichenum Dejean, 1834

Endothina Carter, 1924

\section{Lichenum auctorum}

Leichenum canaliculatum (Fabricius, 1798)

Opatrum canaliculatum Fabricius, 1798

Opatrum canaliculatum variegatum Klug, 1833

Leichenum pulchellum Küster, 1849

Leichenum variegatum Küster, 1849

Leichenum argillaceum Motschulsky, 1863

Lichenum foveistrium Marseul, 1876

Lichenum seriehispidum Marseul, 1876

Lichenum gebieni Reitter, 1906

Endothina squamosa Carter, 1924

\section{Distribution}

Country records include, but are likely not limited to, the following: Australia, Botswana, Cameroon, Chad, Cuba, France, Gambia, Guadeloupe, India, Italy, Japan, Kenya, Liberia*, Mozambique, Namibia, Niger, Nigeria, Senegal, Somalia, South Africa, Spain, Sri Lanka, Sudan, Tanzania, Thailand, and Vietnam* (Marcuzzi 1984, Penrith 1984, Ferrer 2002, Peck 2005, Steiner 2005, Australian Faunal Directory 2007, Tenebrionidae.net 2007).

In the United States, this species has been found in coastal areas of Alabama [Mobile and Baldwin Counties (Löding 1945)]; Georgia [Camden*, Charlton, and Thomas* Counties (Spilman 1959)];

Mississippi [George, Harrison*, Jackson, and Stone Counties (Spilman 1959)]; North Carolina [Columbus*, Dare*, Hyde*, and New Hanover Counties (Spilman 1959)]; South Carolina [Anderson, Barnwell, Florence, Horry, and Sumter Counties (Kirk 1969, Kirk 1970), Oconee County (Spilman 1959)]; and in Florida. Additional locality records undoubtedly occur in public and private insect collections.
In Florida, it occurs throughout the state. Confirmed Florida records include the following counties (from Peck and Thomas 1998): Alachua, Broward, Clay, Dade, Dixie, Duval, Hardee, Highlands, Indian River, Lake, Lee, Levy, Marion, Orange, Palm Beach, Polk, St. Lucie, Santa Rosa. Spilman (1959) also reported it in Florida from Escambia, Hendry, Manatee, Putnam, Wakulla, and Washington counties. Additional Florida records, taken from label data on specimens housed in the Florida State Collection of Arthropods (as of April 2007), include the following counties: Monroe and Okaloosa. The junior author included records from Collier* and Franklin* counties.

* specimens in collection of U.S. National Museum of Natural History, Smithsonian Institution

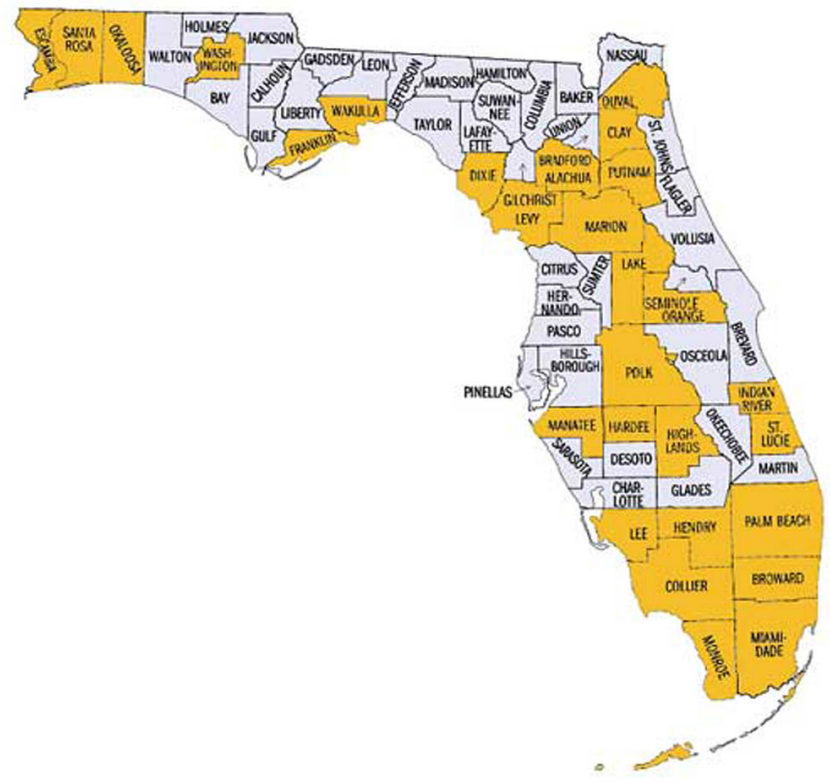

Figure 2. Florida distribution- April 2007. Credits: James C. Dunford, University of Florida

\section{Description}

The beetle does not closely resemble any other tenebrionid species in Florida and should be readily recognized. However, a native tenebrionid, Ammodonus fossor (LeConte), inhabiting similar sandy habitats that could potentially occur in Florida (especially in the panhandle) does superficially resemble $L$. c. variegatum. Ammodonus fossor is known throughout much of the eastern United States, and at present the southernmost locality records include Alabama (Löding 1945), South Carolina, and Texas (Kirk 1969, Steiner 2000). 


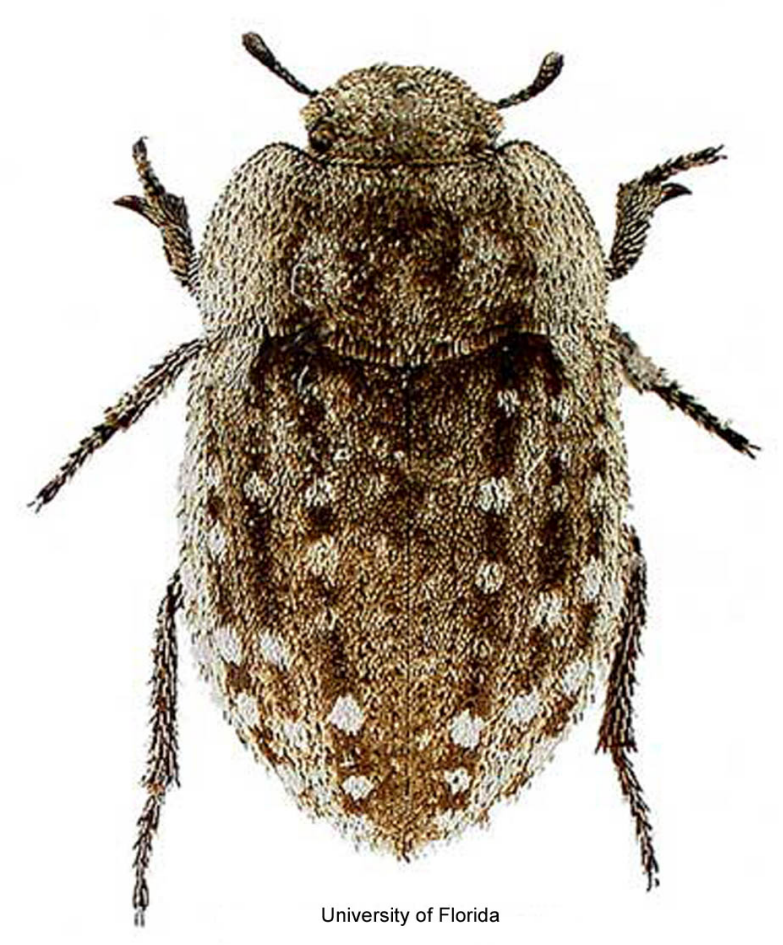

Figure 3. Adult Ammodonus fossor (LeConte), a native tenebrionid beetle. Credits: Warren E. Steiner, Jr., U.S. National Museum of Natural History, Smithsonian Institution

Adult: The Leichenum c. variegatum adult is oval and approximately $5 \mathrm{~mm}$ in length. The body appears gray, although actually mottled with black, gray, brown, and whitish spatula-shaped, scale-like setae. This mottling is sometimes variable, depending on the number of these scale-like setae that have been rubbed off. The eyes are globose and slightly emarginated, with erect setae between facets. The setae located between the facets are hypothesized to protect the eyes from damage when they burrow into the sand (Medvedev 1973). The antennae are short with a clearly defined 4-segmented club on the apical half.

Larva: The larva resembles a small wireworm in general appearance. The description provided in St. George (1930) included morphological characters that are associated with members of the Opatrinae (Leichenini) but no adult association and definitive species determination was made. However, the junior author confirmed the description provided by St. George by examining larvae and pupae that were reared from captive adults. The length of the mature larva is $12 \mathrm{~mm}$.

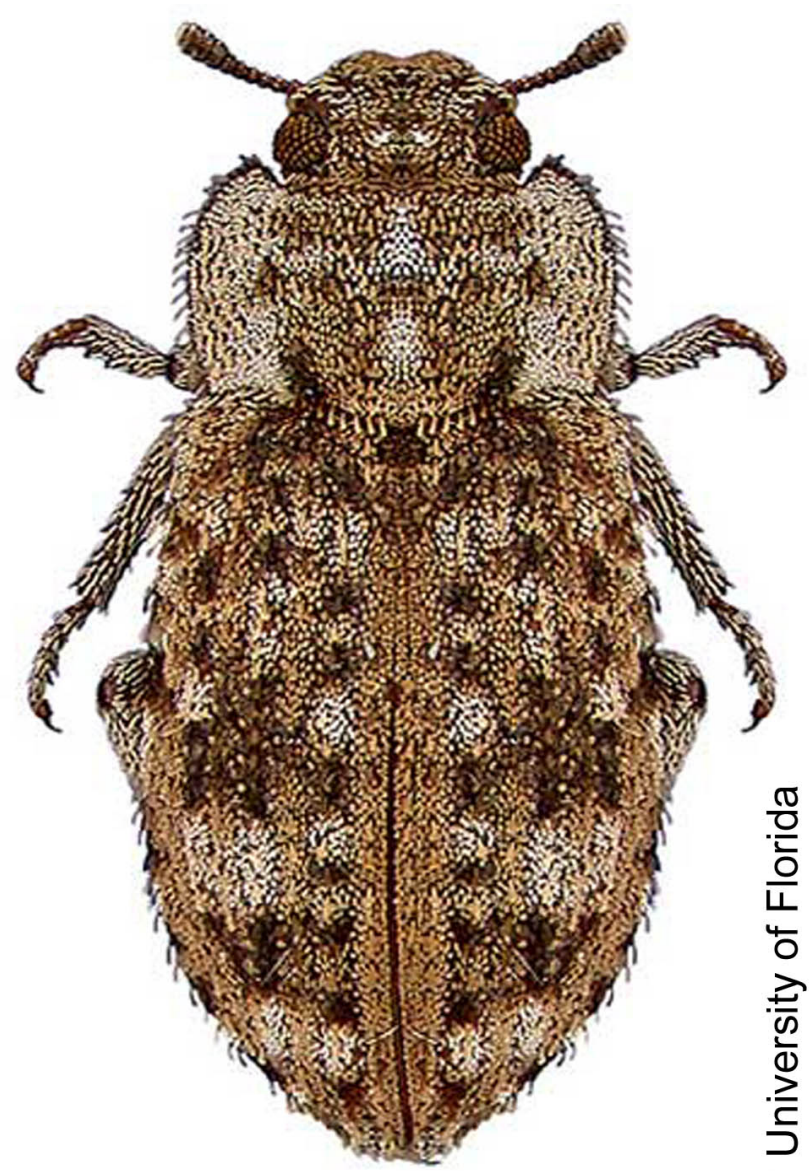

Figure 4. Adult Madagascar beetle, Leichenum canaliculatum variegatum (Klug). Credits: James C. Dunford, University of Florida

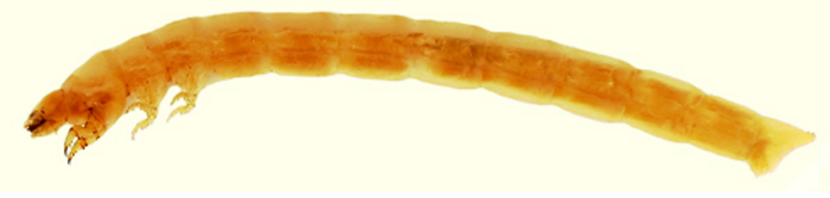

Figure 5. Larva of the Madagascar beetle, Leichenum canaliculatum variegatum (Klug). (Lateral view, head on left). Credits: Warren E. Steiner, Jr., U.S. National Museum of Natural History, Smithsonian Institution

Head: The dorsal half of the head capsule is not setose but the lateral margins and ventral half is slightly setose. The ocelli are arranged in a single transverse group on each side. The clypeus bears two spines and two setae, one of each on each side. The labrum bears two spines, one on each side, or six spines, three on each side. The back of the mandible opposite of the cutting edge is slightly sharp, and opposite the molar area there is a membranous elevation bearing one or two setae anteriorly and many short, thick spines posteriorly. The apices of 
both mandibles are bifid with an additional dorsal tooth between the apex and the molar part.

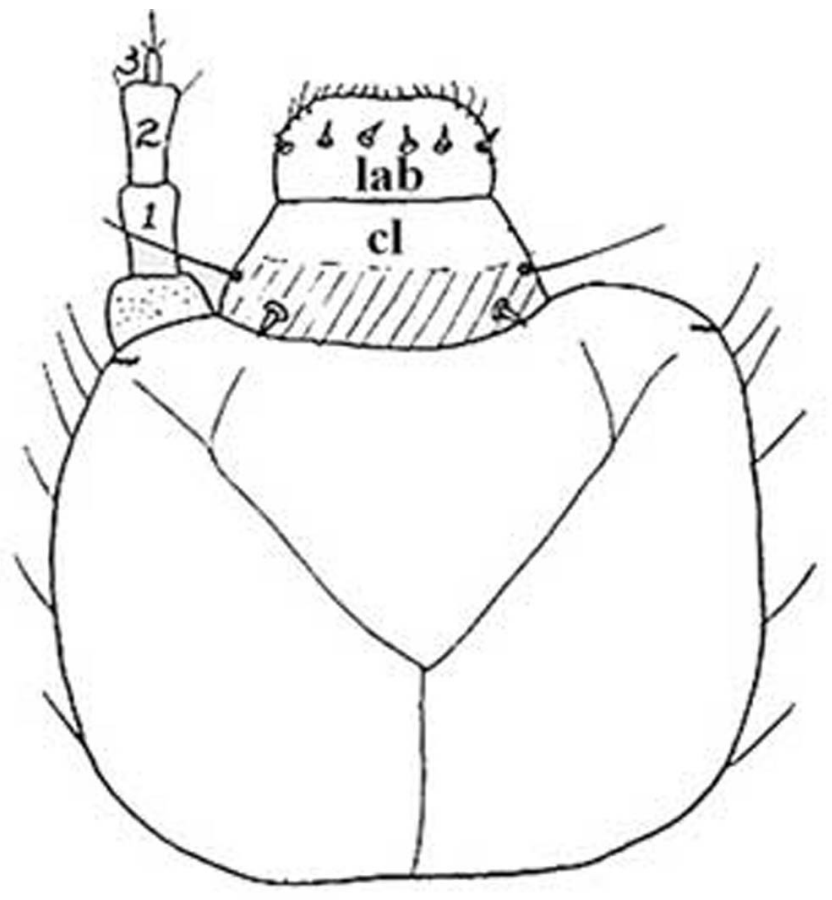

Figure 6. Larval head, Leichenum c. variegatum. Credits: St. George 1930

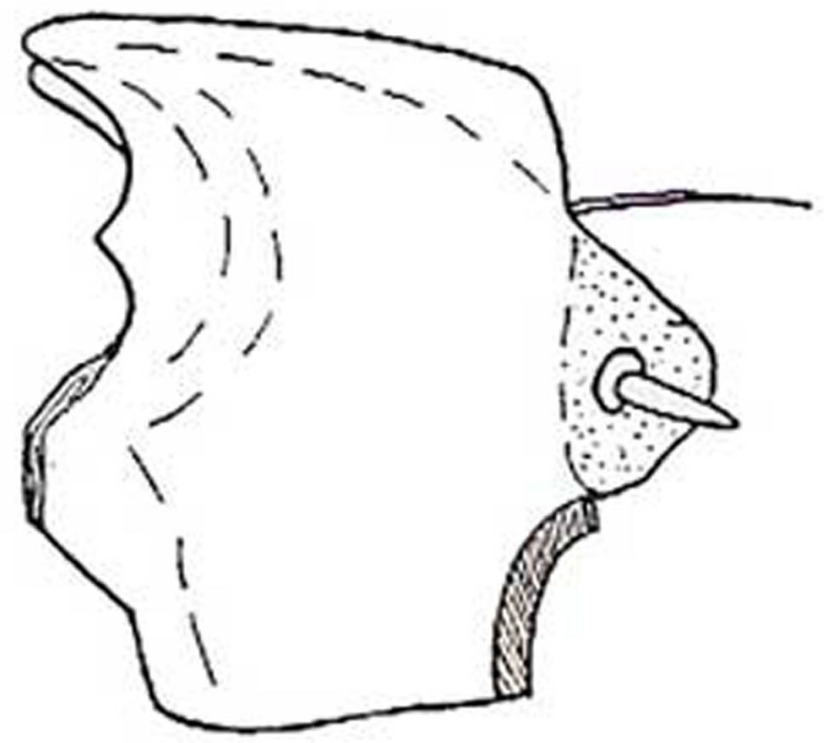

Figure 7. Larval mandible, Leichenum c. variegatum. Credits: St. George 1930

Thorax: The prothoracic legs are larger than the other two pairs.

Abdomen: The abdominal spiracles are annular (ring-shaped) in shape. The ninth abdominal segment is shorter than the eighth, subconically produced and obtusely pointed. The lateral margins bear two to eleven setae on each side and additional scattered, fine setae elsewhere on the segment; the tergum otherwise without setae but with one anterior and one posterior pair of setae; the sternum bears a few setae, often arranged in a transverse row. There are also two distinct pairs of stout, dark setae near the apex.

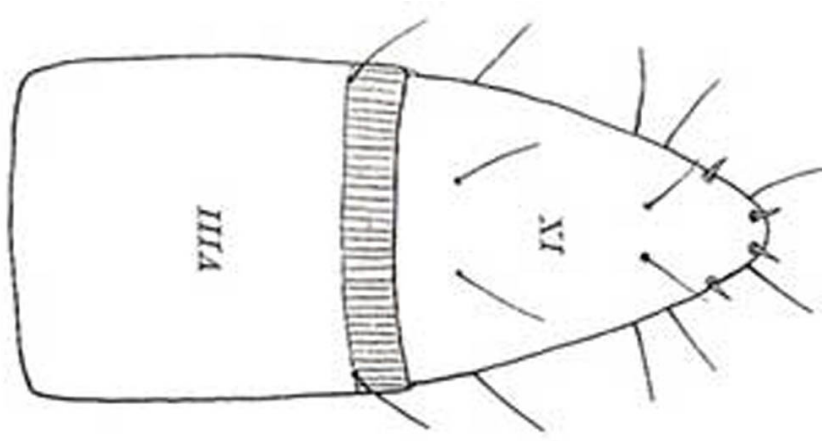

Figure 8. Abdominal segments VIII and IX, Leichenum $c$. variegatum larva. Credits: St. George 1930

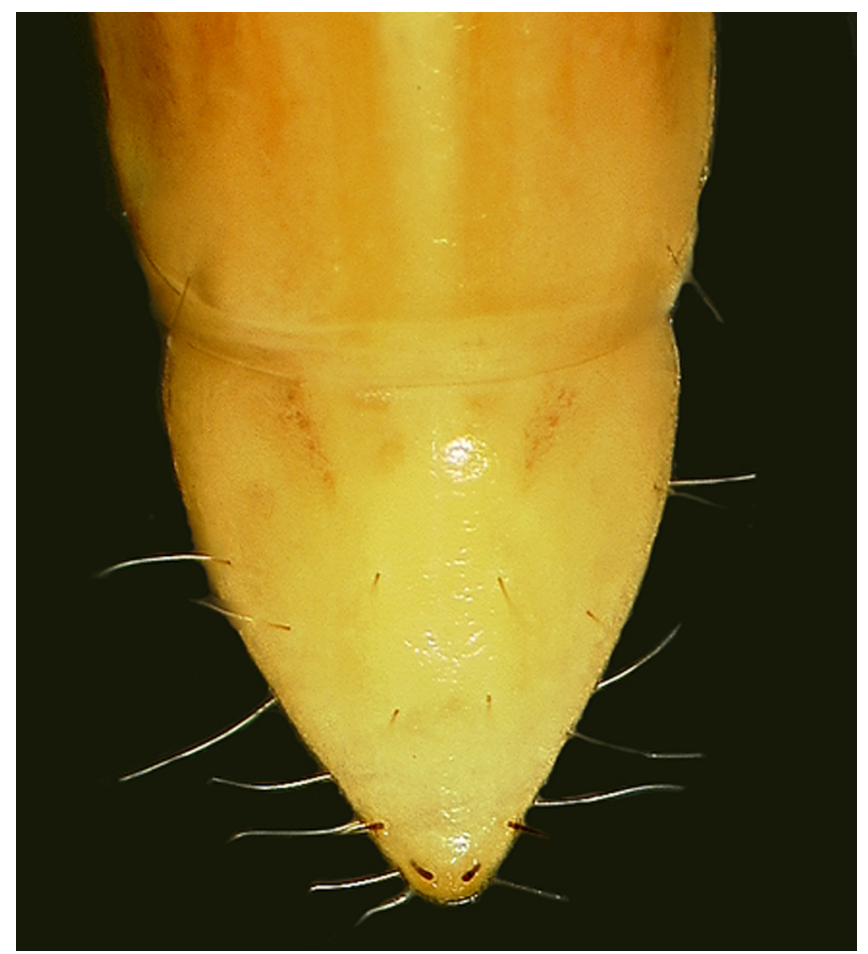

Figure 9. Ninth abdominal segment of the larva of the Madagascar beetle, Leichenum canaliculatum variegatum (Klug). (Dorsal view.) Credits: Warren E. Steiner, Jr., U.S. National Museum of Natural History, Smithsonian Institution

Pupa: Steiner (1995) provided a partial description of the pupa. The urogomphi (paired processes from the posterior end of the tergum of the ninth abdominal segment) are fused into a long 
spine-like process and the tip ends in two small round lobes. The pupa is $6 \mathrm{~mm}$ in length, including the fused urogomphi.

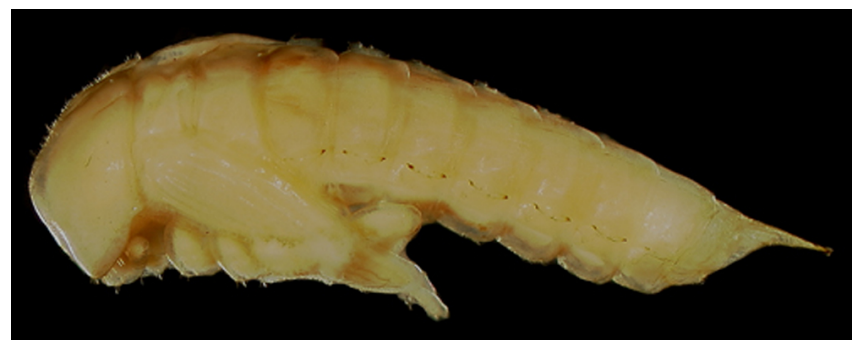

Figure 10. Pupa of the Madagascar beetle, Leichenum canaliculatum variegatum (Klug). (Lateral view, head on left). Credits: Warren E. Steiner, Jr., U.S. National Museum of Natural History, Smithsonian Institution

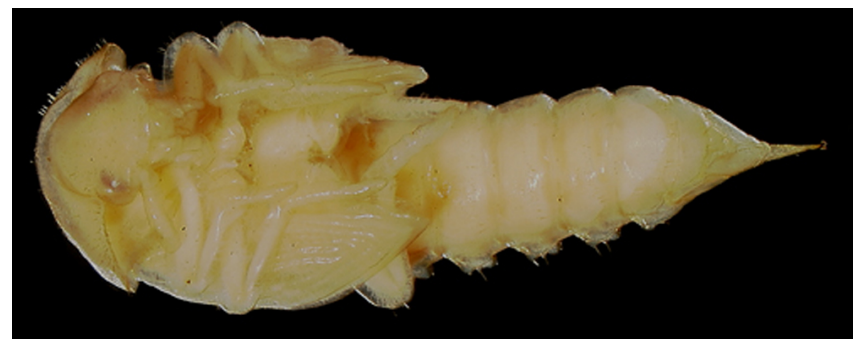

Figure 11. Pupa of the Madagascar beetle, Leichenum canaliculatum variegatum (Klug). (Ventral view, head on left). Credits: Warren E. Steiner, Jr., U.S. National Museum of Natural History, Smithsonian Institution

\section{Habits and Biology}

The adult beetles are attracted to light (specifically mercury vapor lights on some specimen labels), and this offers a good survey procedure. Baited or unbaited pitfall traps may also work. The beetle seems to occur more commonly in sandy areas, along beaches (occasionally taken under boards or debris), lake and river shorelines, and has been recorded from March to November, although it probably occurs throughout the year (Woodruff 1963). Steiner noted that he has collected adults in areas of very open, mostly bare, dry, loose sand with minimal vegetation and never on the tidal zone of a beach but above it on low dunes or sand flats behind dunes. Often these are "disturbed" or "waste" areas such as edges of heavily used paths and mowed areas. Adults usually hide under small piles of leaf litter in sand depressions (as do Ammodonus fossor adults) and at the crowns of small plants in sand; they do not seem to burrow very deep. They can be found foraging on the sand at night or occasionally during cooler times of day.

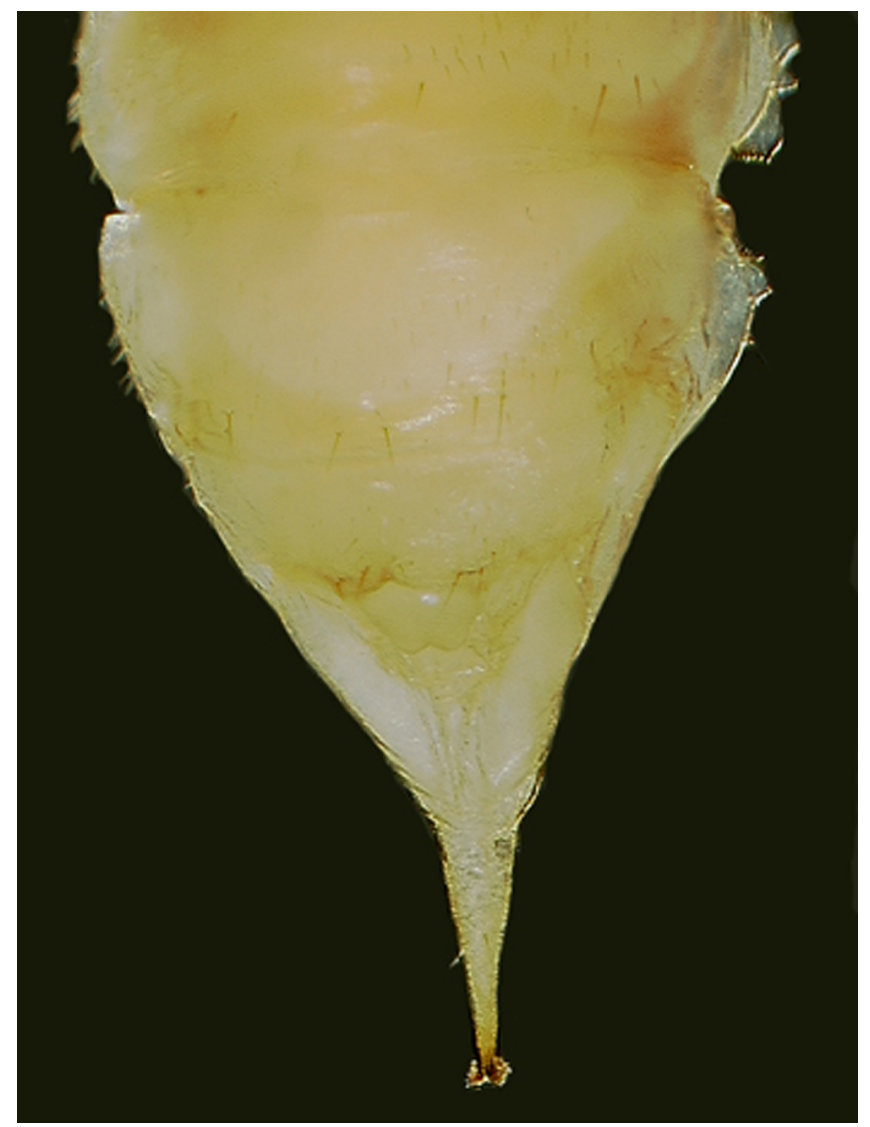

Figure 12. Fused urogomphi of the pupa of the Madagascar beetle, Leichenum canaliculatum variegatum (Klug). Credits: Warren E. Steiner, Jr., U.S. National Museum of Natural History, Smithsonian Institution

\section{Economic Importance}

We have no definite record of damage being caused by this beetle, but it has often been incriminated by its presence. Both adults and larvae are found in the soil and both stages probably feed on roots of plants. It has been recorded in Bermuda grass, cotton, soil among turnips and rutabagas, feeding on nap of rugs, and associated with damaged peach trees and Amaryllis bulbs (Spilman 1959, St. George 1930).

\section{Selected References}

Aalbu RL, Triplehorn CA. 1985. Redefinition of the opatrine tribes in North America with notes on some apterous genera (Coleoptera: Tenebrionidae: Tenebrioninae). The Coleopterists Bulletin 39: 272-280.

Aalbu RL, Triplehorn CA, Campbell JM, Brown KW, Somerby RA, Thomas DB. 2002. Family 106. 
Tenebrionidae Latreille 1802, p. 463-509. In

American Beetles. Volume 2. Polyphaga:

Scarabaeoidea through Curculionoidea (Arnett Jr RH, Thomas MC, Skelley PE, Frank JH, eds.). CRC

Press, Boca Raton, FL.

Australian Faunal Directory. (2007). Australian

Faunal Directory Checklist Tenebrionidae. Australian Government Department of the Environment and Water Resources. http://www.environment.gov.au/biodiversity/abrs/ online-resources/fauna/afd/ (12 April 2007)

Blanchard E. 1845. Histoire naturelle des insects, leurs moeurs, leurs métamorphoses et leur classification ou traité élémentaire dentomologie. Tome second. F. Savy, Paris. 524 pp.

Bouchard P, Lawrence JF, Davies AE, Newton AF. 2005. Synoptic classification of the world Tenebrionidae (Insecta: Coleoptera) with a review of family-group names. Annales Zoologici 55: 499-530.

Carter HJ. 1924. Australian Coleoptera - notes and new species. No. iv. Proceedings of the Linnean Society of New South Wales. 49: 521-544.

Dejean PFMA. 1834. Iconographie des Coléoptères de la collection de M. Le Baron Dejean livr. 3, pp. 176-256, Paris.

Fabricius JC. 1798. Supplementum entomologiae systematicae, Hafniae, 572 pp.

Ferrer J. 2002 Nouvelles localisations de Leichenum africains (Coleoptera, Tenebrionidae, Leichenini). Nouvelle Revue dEntomologie, N.S. 19: 10 .

Gridelli E. 1939. Coleotteri dell'Africa orientale italiana. 10 contributo revisone delle specie del genre Leichenum Blch. (Coleopt. Tenebrionidae). Atti del Museo Civico di Storia Naturale - Trieste 14: 207-242.

Kirk VM. 1969. A list of the beetles of South Carolina Part 1- Northern Coastal Plain. South Carolina Experimental Station Technical Bulletin 1033.
Kirk VM. 1970. A list of the beetles of South Carolina Part 2 - Mountain, Piedmont, and Southern Coastal Plain. South Carolina Experimental Station Technical Bulletin 1038.

Klug JCF. 1833. Berich über eine auf Madagascar veranstaltete Sammlung von Insecten aus der Ordnung Coleoptera. Abhandlungen der Preussiche Akademie der Wissenschaften, pp. 91-223.

Küster HC. 1849. Die Käfer Europas Nürnberg : Bauer und Raspe.

Leng CW. 1920. Catalogue of the Coleoptera of America, north of Mexico. Mt. Vernon, New York, $470 \mathrm{pp}$.

Löding HP. 1945. Catalogue of the beetles of Alabama. Geological Survey of Alabama Monograph 11: 1-172.

Marcuzzi G. 1984. A catalogue of Tenebrionid beetles (Coleoptera: Heteromera) of the West Indies. Folia Entomologica Hungarica. 45: 69-108.

Marseul SA. 1876. Coléoptères du recuillis par M. Georges Lewis. 2nd edition. Mèmoire. énumération des Hétérom\&egrave;res, avec la description des espèces nouvelles. Part 1. Annales de la Société Entomologique de France 5: 93-142.

Medvedev GS. 1973. The position of the genera Leichenum (Dej. and Idisia Pask. (Coleoptera, Tenebrionidae) in the system, and the description of a new genus from northern Karakums. Entomological Review 52: 428-433.

Motschulsky V. 1863. Essai d'un catalogue des insectes de l'îsle de Ceylan. Bulletin de la Société Impériale des Naturalistes de Moscou 36: 421-532

Peck SB, Thomas MC. 1998. A Distributional Checklist of the Beetles (Coleoptera) of Florida. Arthropods of Florida and Neighboring Land Areas Department of Agriculture and Consumer Services, Gainesville, Florida 16: 1-166.

Peck SB. 2005. A checklist of the beetles of Cuba with data on distributions and bionomics (Insecta: Coleoptera). Arthropods of Florida and Neighboring Land Areas 18: 1-241 
Penrith ML. 1984. The occurrence of the genus

Leichenum Dejean (Coleoptera: Tenebrionidae:

Leichenini) in the northern Namib Desert.

Cimbebasia (Ser. A) 7: 57-65.

Reitter E. 1906. In Heyden L, Reitter E, Weise J. Catalogus coleopterorum Europae, Caucasi et Armeniae rossicae. Edn 2. Berlin, Paskau, Caen.

Spilman TJ. 1959. Notes on Edrotes, Leichenum, Palorus, Eupsophulus, Adelium, and Strongylium (Tenebrionidae). The Coleopterists Bulletin 13: 58-64.

St. George RA. 1930. The discovery of what is possibly the larva of an introduced Tenebrionid, Leichenum variegatum Küst. Proceedings of the Entomological Society of Washington 32: 122-124.

Steiner Jr WE. 1995. Structures, behavior and diversity of the pupae of Tenebrionidae (Coleoptera). In Biology, Phylogeny, and Classification of Coleoptera: Papers Celebrating the 80th Birthday of Roy A. Crowson. Pakaluk J, and Slipinski SA. Muzeum i Instytut Zoologii PAN. Warszawa: 503-539.

Steiner Jr WE. 2000. What flightless beetles in eastern U.S. "micro-deserts" tell us about climatic history and species distribution after the Ice Age. [abstract] 27th Annual Natural Areas Conference, St. Louis, Missouri.

Steiner Jr WE. 2005. Studies on the darkling beetles (Coleoptera: Tenebrionidae) known from Grand Bahama Island, with descriptions of new species of Branchus and Adelina. Proceedings of the Entomological Society of Washington. 107: 441-459.

Tenebrionidae.net. (2007). http://www.tenebrionidae.net/newdesign/ mainpage.htm (12 April 2007)

Woodruff RE. 1963. A Madagascar beetle in Florida, Leichenum canaliculatum variegatum (Klug) (Coleoptera:Tenebrionidae). Florida Department of Agriculture, Division of Plant Industry, Entomology Circular 18. 